\title{
中空糸膜による活性污泥懸濁液の外圧型クロス フロー滤過における污泥堆積過程に関する研究
}

\author{
尾崎則篤 ${ }^{1} \cdot$ 山本和夫 ${ }^{2}$ \\ 1学生会員 工修 東京大学大学院 都市工学専攻（テ113東京都文京区本郷7-3-1） \\ ${ }^{2}$ 正会員 工博 東京大学教授 環境安全研究センター
}

\begin{abstract}
中空糸膜による活性污泥の外圧型クロスフロー憈過において膜糸配置及びクロスフロー流速が污泥堆積過 程に及ぼす影彗を調べた．ある一定值以上のクロスフロー流速では污泥が唯積しなくなることを示した．ま た膜系配置が異なると污泥堆積過程が異なることを示した。 しかし膜間流速及び乱れ強度は膜系配置によら ず一定であった. そこで污泥粒子の膜面への矢突現象のシミュレーションに基づいて, 膜糸配置による污泥 堆䅡開始の違いを説明しうるモデルを提案した。
\end{abstract}

Key Words : membrane separation, hollow fiber membrane, sludge accumulation, crossflow velocity, turbulence intensity, model of particle behavior

\section{1. はじめに}

膜分離技術を用いた下廃水処理法は様々な方向か ら導入が検討され，開発，適用が進められている. 日本におけるビル中水, 屎尿処理への膜分離技術の 適用はその成果といえる.

その中で, 活性污泥法之限外浧過膜等の膜による 固液分離を組み合わせた膜分離活性污泥法は現在開 発が進みつつある分野である．膜分離活性污泥法は 污泥の沈降性によらない安定した処理水質が得ら れ，基本的には污泥引き抜きを必要としない維持管 理が容易な方法となりうる，一方，本法が広く適用 されるには膜分離にかかるコストを低減することが 重要であり，そのために透水能のすぐれた膜素材の 開発, またよりコンパクト化された, 処理効率のよ い膜モジュールの開発が必要になってくる.

膜モジュールのコンパクト化に関しては様々なモ ジュールが考案されている1). なかでも中空系膜は 膜の充填密度を高くすることが容易であり, 容積当 たりの処理効率を大きくすることが可能である.し かし中空系膜の外圧型㵔過では膜糸の充填密度を高 くすることによって膜表面に污泥の堆積が起きると いう問題が生じる. 污泥の堆積は透過水量の低下を 引き起こし膜系の充填密度を上げることによる効果 を相殺する. 滤過の効率を上げるには適切な運転工 程を見いだすこと5,の)，また出来るだけ污泥の堆積を 避けつつ膜系の充填密度を上げるような設計をせね
ばならない。

膜滤過において膜表面への污泥の堆積に影響を与 える因子としてはモジュールの配置, クロスフロー 流速, 污泥の性状, 操作圧力, 操作時間などが ある7),8). 中空糸膜においてはWong9)による活性污 泥の滤過実験によって一定のクロスフロー流速下で は，ある程度以上膜糸密度が上がると污泥の堆積が 生じ，それにより急激なフラックスの低下を引き起 こすことが明らかになった. そこで, 污泥堆積を避 けつつ膜系密度を上げるには膜系密度がどのような 機構で污泥堆積に影響を与えるのかを調べることが 重要になってくる.

本研究の目的は中空系膜において膜系の充填密度 が污泥堆積に及ぼす影響を，構造を単純化した膜モ ジュールを用いることにより詳細に解析することで ある. そこで正三角形状に配置された 3 本の中空系 膜モジュールが外圧型中空糸膜モジュールを構成す る基本単位となるとし，3本の膜を持つ中空糸膜を 用いた解析を行った. 3 本の膜モジュールは, 膜系 に囲まれた領域が存在しうる最小の本数であり，そ こでの解析は一般の, 多くの膜糸を含む膜モジュー ルの堆積機構の解明の基礎となりうるものである.

まず活性污泥の滤過実験によってクロスフロー流 速と膜系の充填密度が污泥の堆積量にどのように影 響を与えるのかを調べた. 一方潈過実験による結果 をうけ, 膜モジュールを清水に設置し膜近傍の流速 を測定し, 流速および乱れ強度と污泥付着量との関 


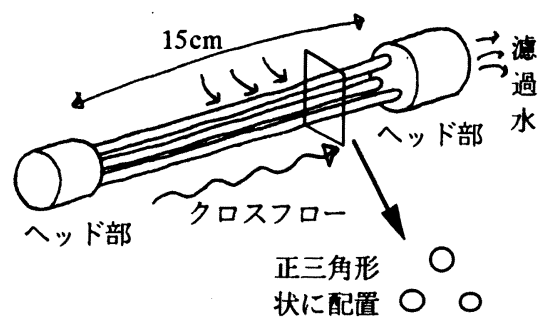

図ー1 膜モジュールの形状

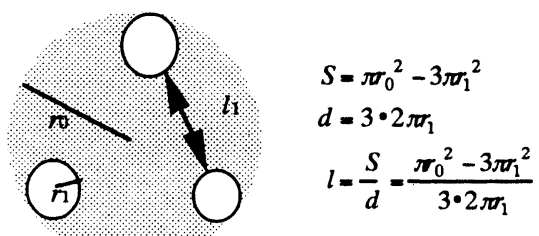

: 膜系を囲む領域 $S$

: 膜系断面 (周長 $d$ )

$l_{1}:$ 通常の意味での膜間距離

$l:$ 一般化された膜間距離

図一2 膜系断面と一般化された膜間距離の計算

表一 1 膜の仕様

\begin{tabular}{|c|c|}
\hline $\begin{array}{c}\text { サイズ } \\
\text { 素材 } \\
\text { 分画分子量 } \\
\text { 純水フラックス } \\
\text { 構造 }\end{array}$ & $\begin{array}{c}\text { 外径 } 2 \mathrm{~mm} \text { 、内径 } 1.2 \mathrm{~mm} \\
\text { ポリスルフォン系 } \\
\text { 約 } 20,000 \text { 、限外濾過膜 } \\
1.2 \mathrm{~m} \cdot \mathrm{d}^{1} \mathrm{at} 70 \mathrm{kPa}, 25^{\circ} \mathrm{C} \\
\text { 外㑡に活性層、内側に支持酋 }\end{array}$ \\
\hline
\end{tabular}

連を調べた。

また活性污泥粒子の挙動を記述した数值シミュ レーションに基づいた膜系充填密度と污泥堆積の関 係に関する考察を行った.

\section{2. 膜系配显と污泥付着量}

\section{（1）活性污泥の減迥においてクロスフロー流速お

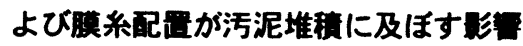

\section{a) 実験方法}

実験に用いた膜は表一 1 に示す仕様のものであ る. 膜モジュールの形状を図ー 1 に示す. 3 本の膜 糸が正三角形状に配置されている. 管径 $20 \mathrm{~mm}$ の円管 中央に膜モジュールを固定する. 膜糸の位置の固定 は両ヘッド部によってなされる. 滤過水は片側集水 である. 膜糸部分の断面を図一 2 に示す.

膜糸の配置におけるその分散の度合いの指標とし て一般化された膜間距離を以下のように定義する。

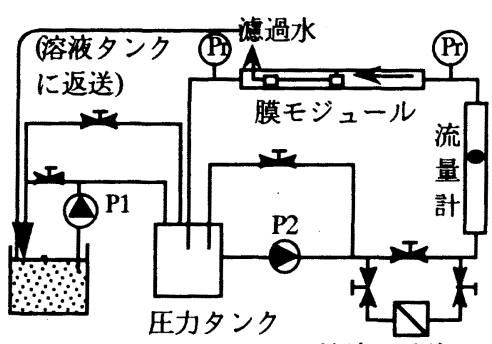

溶液タンク

溶液の洗浄用

（純水のみ）

図-3 実験装置の配置

$$
l=\frac{S}{d}
$$

ただし, $l:$ 一般化された膜間距離 $[\mathrm{mm}], s$ : 膜糸を 囲む領域の断面積 $\left[\mathrm{mm}^{2}\right], d:$ 膜糸断面の周長 $[\mathrm{mm}]$ で ある. 図ー2に各々の示す部分について記した.こ の定義による膜間距離は通常の意味での膜間距離が0 のときも膜糸に囲まれた領域と膜糸の外に空隙がで きるため0にはならない. 本研究で用いた膜モジュー ルでは. 一般化された膜間距離 $0.3 \mathrm{~mm}$ が通常の意味 での膜間距離 $0 \mathrm{~mm}$ に相当している. 本論文では，特 に通常の意味での膜間距離と区別するべき場合を除 き一般化された膜間距離を「膜間距離」と呼ぶ.

活性污泥を外圧式でクロスフロー滤過をし, 膜間 差圧は70 kPa, MLSSは1.2 1.8 $\mathrm{kg} \cdot \mathrm{m}^{-3}$, 水温は $25^{\circ} \mathrm{C} て ゙$ あった. 活性污泥はグルコース, ペプトンを中心と した基質を用い. Fill and Draw方式で污泥滞留時間 (SRT)は10日とした.

実験装置の概要を図ー 3 に示す．溶液タンクで污 泥は培養されポンプP1によって圧力タンクに送られ る.P1はまた膜間差圧を与える役割をもつ. 循環流 によるクロスフローはポンプP2によって与えられ る. 二つのポンプと, 弁によって圧力とクロスフ ローが独立に調節される．滤過水は再び容液タンク に返送される.一つの滤過実験の期間は 3 日ないし 4 日であり, 膜糸配置またはクロスフロー流速を変 えて、それぞれの濾過実験を行った. 滤過実験中も Fill and Drawを継続して行い, 污泥の性状を一定に 保った.

測定項目は活性污泥滤過時のフラックス（体積フ ラックス）および, 濾過実験終了後に膜表面に付着 した污泥の重量である. 付着した污泥の重量は活性 污泥の滤過終了後, 膜モジュールを取り出し, キム ワイプで膜表面の污泥をふき取りモジュールをふき 取る前後の重量差から計算した. またふき取った污 泥は $105{ }^{\circ}$ Cで 2 時間強熱乾燥させ, 再び重量を測 

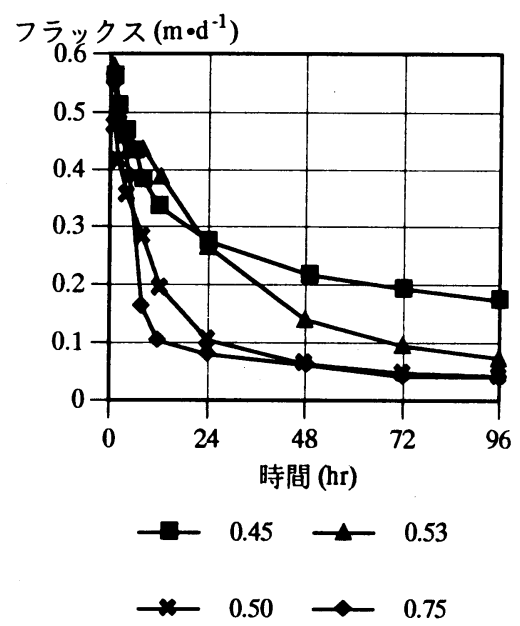

数字は膜間距離 $(\mathrm{mm})$

(クロスフロー流速 $0.53 \mathrm{~m} \cdot \mathrm{s}^{-1}$ )

図一４フラックスの経時変化

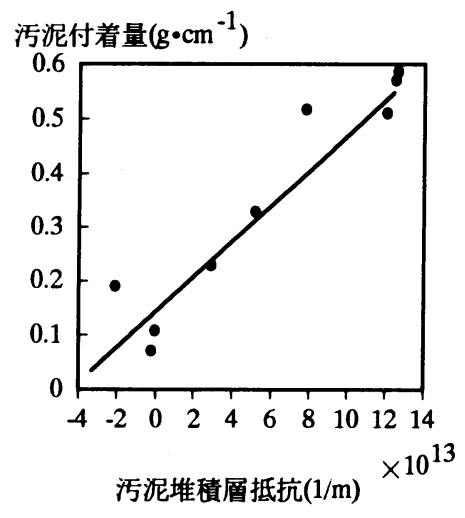

図-5 污泥堆積層抵抗之污泥堆積量

定し付着した污泥の含水率を計算した．污泥は膜系 全体に一様に堆積しているとし, 膜系の長さで除し た値で污泥付着量を表した.

濾過はまずクロスフロー流速を一定にし，様々な膜 間距離を持つ膜モジュールを用いておこない, 污泥 付着量とフラックスとの関係を調べた. またフラッ クスの経時変化に基づき污泥堆積層抵抗を求め膜間 距離との関係を調べた.

また様々なクロスフロー流速で㴗過を行いクロスフ ロー流速とフラックス, 污泥付着量との関係を調べ た.

\section{b) 実験結果}

図ー4に膜間距離を変えて行った場合のフラックス の経時変化を示す.

次にこれらフラックスの値に基づき污泥堆積層抵抗
を算出し, 污泥付着量との比較を行う.

フラックスと膜間差圧, 滤過総抵抗には以下の関係 がある.

$$
R_{T}=\frac{\Delta P}{\mu J}
$$

ここにJ: フラックス $\left[\mathrm{m} \cdot \mathrm{s}^{-1}\right], \Delta P$ : 膜間差圧 $[\mathrm{Pa}], R_{T}$ : 濾過総抵抗 $\left[\mathrm{m}^{-1}\right], \mu:$ 粘性係数 $[\mathrm{Pa} \cdot \mathrm{s}]$ である.

また, 濾過総抵抗 $R_{T}$ は, 膜抵抗 $R_{m}\left[\mathrm{~m}^{-1}\right]$, 膜内の目詰 まりによる抵抗 $R_{i}\left[\mathrm{~m}^{-1}\right]$, 污泥堆積層抵抗 $R_{c}\left[\mathrm{~m}^{-1}\right]$ を用い ると。

$$
R_{T}=R_{m}+R_{i}+R_{c}
$$

と表される.

滤過時に污泥堆積を起こさなかった場合, 污泥堆積 層抵抗は生じず, $R_{c}=0$ となり,$R_{T}=R_{m}+R_{i}$ となる. そこで, この場合の濾過総抵抗を $R_{T 0}$ とすると, 污泥 堆積層抵抗は

$$
R_{c}=R_{T}-R_{T 0}
$$

として計算される.

同じ時間滤過を行ったとしても，一般には污泥堆積 が起きた場合と起きなかった場合とでは膜内の目詰 まりによる抵抗 $R_{i}$ が異なる.これは主として㴓過水量 が異なってくるため濾過水が膜を透過する際に付着 する目詰まりの量が異なってくるからである. しか し本実験中, 最も污泥堆積が多かった場合とほとん ど堆積が起きなかうた場合とでは, 滤過総水量が最 大 2 倍程度の開きがあったにもかかわらず，洗浄に よって表面の污泥を取り除いた後の純水フラックス には 1 割程度しか差がなかった.このことから，本 実験においては濾過実験ごとに污泥付着量が異なっ ていても膜内目詰まり抵抗に大きな差はなく, 本実 験においては污泥堆積が異なっていても目詰まり抵 抗は等しいといえる.

本実験においてはクロスフロー流速が一定であって も, 污泥付着が甚だしいものとほとんど污泥が付着 しないものに分かれフラックスに大きな差が生じる ことが観察された. 本実験の目的はなぜ膜間距離に よって污泥付着量が様々な異なる值をとるかを調べ ることである. そこで污泥の付着がほとんど起きな かった膜モジュールの抵抗を $R_{T 0}$ と見なし，それ以外 の各々の膜モジュールの抵抗との差として污泥堆積 層抵抗 $R_{c}$ を式(4)から計算し污泥付着量との関係を調 べた.

图一 5 に㴓過終了時における污泥堆積層抵抗と, 污 泥付着量との関係を示す. 污泥堆積層抵抗と污泥付 着量は一定の直線関係を持っている. 污泥付着量は 污泥堆積層抵抗が0の時でも 0 にはならず正の值を 持っている.これはどの濾過においても全く污泥付 


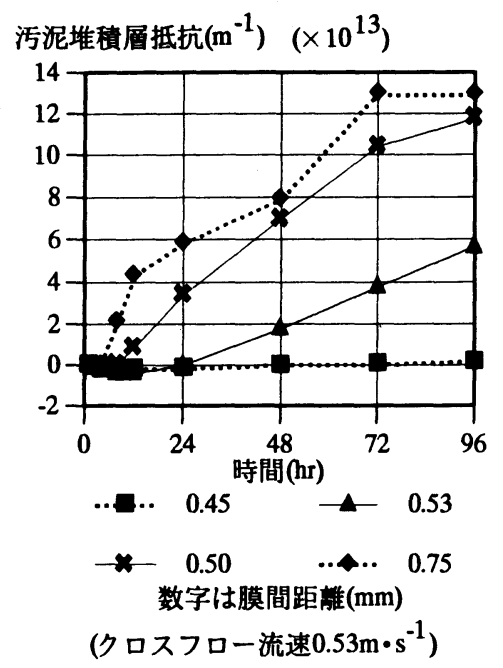

图一 6 污泥堆積層抵抗の経時変化の例

着が起きないというわけではなく污泥付着がわずか ながら生じるためである．また，污泥堆積層抵抗が 負値をとる部分があるが，式(4)において異なる膜モ ジュールとの差をとっているために生じた誤差であ ると考えられる.

污泥付着量は直接には㥁過終了時に膜を取り出さ ねば測ることは出来ない。しかし，一旦图一 5 が得 られれば、式(2) 式(4)によって定義された污泥堆積 層抵抗に基づき污泥堆積量の経時変化を推定するこ とが可能になることが分かる.

図一 6 に污泥堆積層抵抗の経時変化の例を示し た. 抵抗は㥁過開始後一定の時間を経て生じ始めて いる. すなわち污泥の堆積は濾過開始後, ある程度 時間が経過して後生じる. また堆積開始に要する時 間は膜間距離によって異なっている.

そこで膜間距離と，㓡過開始後，污泥堆積が始ま るのに要する時間（污泥堆積開始時間）との関係を 図ー 7 に示した．全体として下に凸の傾向を持ち. 膜間距離 $0.8 \mathrm{~mm}$ 程度が最も污泥の堆積開始時間が早 い. 膜間距離による違いが污泥堆積が開始される時 間の違いにあらわれているのが分かる.

膜間距離 $1.4 \mathrm{~mm}$ 付近に污泥堆積開始時間が非常に 小さく, 他と傾向の異なる実験結果がある（括弧で 括ったプロット）。このとき, 原因は不明だが污泥 の性状が他のものに比べて見かけ粘性が高くなって いたことが観察され，污泥の性状の変化が膜面への 付着の起きやすさに影響を与えたのではないかと考 えられる。

また図ー 8 に膜間距離と污泥堆積層抵抗の增加速 度との関係を示した. 堆積速度の差は最も大きいも

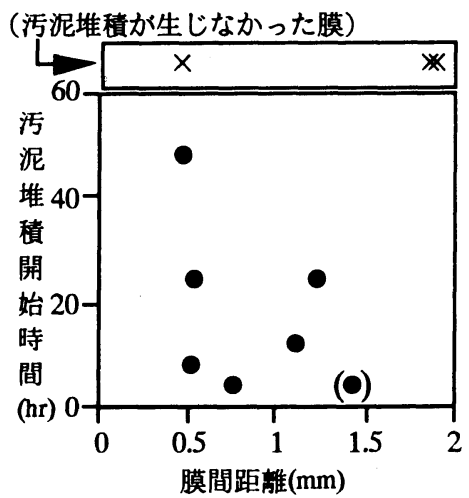

（濾過において污泥堆積を起こさ なかった場合を上に別に示した）

図一7 膜間距離之污泥堆積開始時間

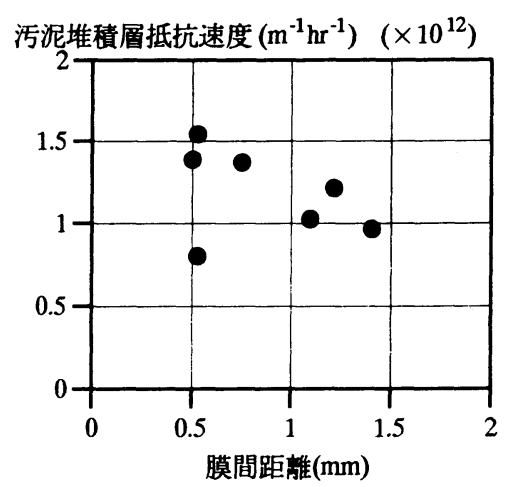

図-8 膜間距離之污泥堆積層抵抗の增加速度

のでも 2 倍程度であり, 最大 10 倍以上の差が出た 污泥堆積開始時間と比較すると差はそれほど顕著で はない.

また異なるクロスフロー流速下で渚過実験を行い クロスフロー流速の違いによる污泥堆積の違いにつ いて調べた.

図ー 9 に，滤過開始後 72 時間経過した時点での フラックスを定常フラックスと見なし，異なるクロ スフロー流速下における定常フラックスを示した. また，図一 10 に活性污泥実験終了時の，膜の表面 の污泥付着量を示した. 図一 9 とあわせてみると， クロスフロー流速一定のもとでは污泥付着量が大き いときは定常フラックスは小さく, 污泥付着量が小 さいときは定常フラックスが大きいといえる.

また，污泥の堆積状態を観察したところ，下流部 ほど堆積量が大きくなるという傾向を持っていた が，おおむね均一に堆積を起こしていた。

また污泥の含水率も測定し．95 $0.5 \%$ とほぼ一定の 值を得た.

図ー10において．クロスフロー流速一定のもと 


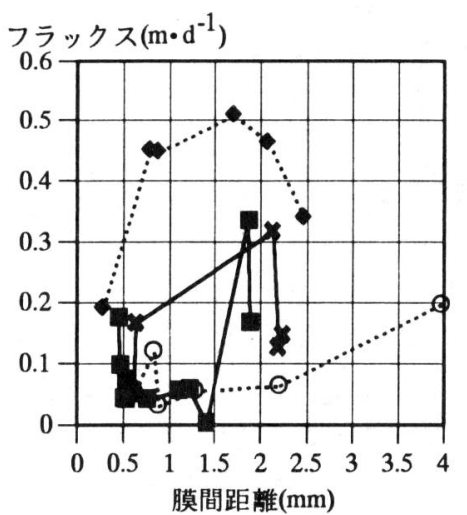

$\rightarrow-0.53 \mathrm{~m} \cdot \mathrm{s}^{-1}$

.๑. $0.62 \mathrm{~m} \cdot \mathrm{s}^{-1} \quad$ クロスフロー流速

$\rightarrow 0.70 \mathrm{~m} \cdot \mathrm{s}^{-1}$

..*.. $1.1 \mathrm{~m} \cdot \mathrm{s}^{-1}$

図-9

各クロスフロー流速下における膜間距

離とフラックス
膜系長さ当たり堆積污泥量 $\left(\mathrm{g} \cdot \mathrm{cm}^{-1}\right)$

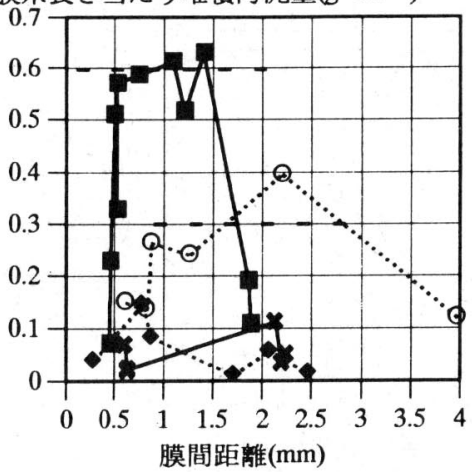

$\rightarrow-0.53 \mathrm{~m} \cdot \mathrm{s}^{-1}$

.๑.. $0.62 \mathrm{~m} \cdot \mathrm{s}^{-1}$ クロスフロー流速

$* 0.70 \mathrm{~m} \cdot \mathrm{s}^{-1}$

$1.1 \mathrm{~m} \cdot \mathrm{s}^{-1}$

図- 10

各クロスフロー流速下における膜間

距離と膜系長さあたり堆積污泥量

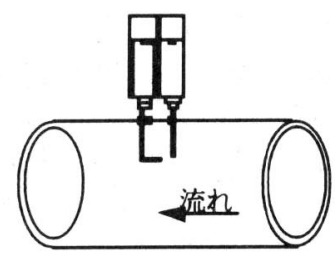

図-11 ピトー管の設定

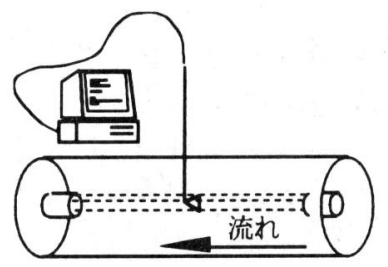

図-12 熱線流速計の設定

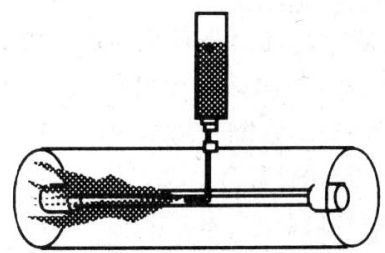

图ー13 トレーサー実験
では最大の污泥付着量が存在し, その最大污泥付着 量はクロスフロー流速が大きくなるに従い小さく なっている. クロスフロー流速 $0.7 \mathrm{~m} \cdot \mathrm{s}^{-1}$ 以上では 0.1 $\mathrm{g} \cdot \mathrm{cm}^{-1}$ 以下と他と比べ非常に小さい值で一定してお り，また実験中の膜糸表面の観察においてもほとん ど污泥の堆積は認められなかった。

\section{（2）膜間领域の平均流速と乱れ強度の測定}

前節の濾過実験で, クロスフロー流速が一定で あっても, 污泥堆積開始時間が膜間距離によって異 なることが分かった. また一定の㥁過時間内に污泥 堆積が起きるか否かも膜間距離によって異なり，そ の差は濾過時間内に污泥堆積開始時間に達するかど うかの差に起因すると考えられる。 そこで污泥堆積 開始時間が短い膜モジュールではその他の膜モ ジュールよりも膜間流速が低下しているのではない
かと考え, 膜間流速を調べるための実験を行った. またトレーサー実験により膜間領域が層流になって いるかどうかを調べた。

清水と活性污泥ではその水理学的性質が異なる が, 本実験条件の範囲では活性污泥の粘性は同じ温 度の清水と比較して高々 1 割程度增加するにすぎ ず，粘性の違いによる水理学的状況の差は無視でき る.

\section{a) 実験方法}

莫間流速の測定

膜糸に囲まれた領域（膜間領域）の中心点での流 速（膜間流速）を測定した. 膜糸に囲まれた狭い領 域の流速を測定するため, 外径 $0.65 \mathrm{~mm}$ のピト一管を 用いた. 図ー11 に示したようにビトー管を流れに おき測定した.

静水管は動水管の測定点の $5 \mathrm{~mm}$ 程度上流, また静 水管が動水管の測定点での流れをなるべく乱すこと 


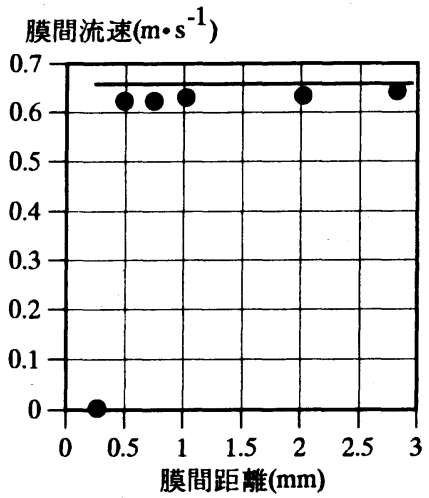

（横線は膜系が設定されて いないときの流速）

\section{図-14 膜間距離と膜間流速}

のないように流れに直角方向に $2 \mathrm{~mm}$ 程度ずらして設 置した. 測定点は膜系上流端から7 $\mathrm{cm}$ 流下したところ であった．管内平均流速は $0.53 \mathrm{~m} \cdot \mathrm{s}^{-1}$ で測定を行っ た.

ピト一管の校正は円管中に設置し流速を測定し， 円管流の速度分布則である1/7乗則と比較することで 行った.

\section{乱れ強度の測定}

測定装置としては熱線流速計（KANOMAX社，モ デル1008,1010,1013）を用い, プローブは幅 $2 \mathrm{~mm} の$ ものを用いた．管内平均流速は $0.53 \mathrm{~m} \cdot \mathrm{s}^{-1}$, サンプリン グレートは50Hzであった.

測定の際は図ー 12 に示したようにヘッド部のみ で，膜糸を除いた状態で設定した．プローブは膜系 上流端相当部から $7 \mathrm{~cm}$ 流下した部分, 円管の中心部に 配した. また比較のためにヘッド部を装着していな い状態，すなわち通常の円管流れでの測定を行っ た.

\section{トレーサー実験}

クロスフロー中の㦟濁液のマクロな流動状況を把 握することを目的としてトレーサ一実験を行った.

トレーサー実験にはピト一管として用いたものと 同じ，先を曲げた注射針を用いてトレーサーを注入 した. トレーサー注入点は膜系上流端から $7 \mathrm{~cm}$ 流下し た部分で, 膜間領域の中心点であった.

またへッド部のみで, 膜糸を設定しない場合でも 測定を行い，クロスフロー中のマクロな乱れが膜系 の有無によって大きく変わるかの比較検討も行っ た. 測定点は円管の中心部, 膜系を設定して測定し た場合と同じ場所に相当する。管内平均流速は $0.53 \mathrm{~m} \cdot \mathrm{s}^{-1}$ であった（图一 13 ），写真撮影によって トレーサーの広がりを観察した．またその写真に基 づき膜糸がある場合とない場合とでトレーサーの広

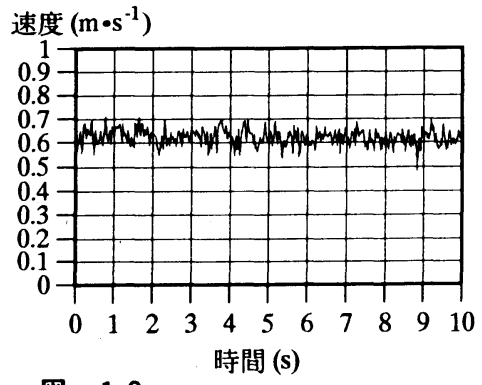

図-16

モジュールを設置していない円管流 中心部の流速

がりの比較を行い, 膜系の存在が乱れ強度にどの程 度影響を及ぼしているかを調べた.

b) 実験結果

膜間流速の測定結果

測定結果を図一 14 に示す. $0.66 \mathrm{~m} \cdot \mathrm{s}^{-1}$ を通る横線 は膜糸を設定していない場合の同じ場所での流速を 示したものである.

一般化された膜間距離 $0.3 \mathrm{~mm}$ （通常の意味での膜間 距離 $0.0 \mathrm{~mm}$ ）以外での膜間流速はほぼ一定値を示し ている.

クロスフロー流速 $0.53 \mathrm{~m} \cdot \mathrm{s}^{-1}$ で行った活性污泥の滤 過実験においては膜間距離 $1.5 \mathrm{~mm}$ 以下で污泥の堆積 を起こしており（図－10），また污泥堆積開始時 間も様々な値を示している（図一7）。しかし膜間 流速はほぼ一定であり污泥堆積開始時間は膜間流速 によらず様々な值を取りうることが分かる.

\section{乱れ強度の測定結果}

管内平均流速を $0.53 \mathrm{~m} \cdot \mathrm{s}^{-1}$ にして測定を行った. 図 - 15 にヘッド部を装着した場合の瞬時流速を，ま た比較のためへッド部を装着していない場合の円管 中心部の瞬時流速を図ー16 に示した（これは通常 の円管乱流の流速を測定したことになる）。

乱れ強度は9.9 $\times 10^{-2} \mathrm{~m} \cdot \mathrm{s}^{-1}$, ヘッド部を設定してい ない場合 $3.1 \times 10^{-2} \mathrm{~m} \cdot \mathrm{s}^{-1}$ であった.ヘッド部を装着し た場合，装着していない場合の乱れ強度の3.4倍程度 となっており上流の端部の存在が相当乱れ強度を大 きくしているのが分かる.

\section{トレーサー実験結果}

膜間距離 $0.8 \mathrm{~mm}, 3.2 \mathrm{~mm}$ の膜モジュールでトレー サ一実験をおこなった結果，いずれもトレーサー注 入点を頂点とする紡鍾状の広がりを見せた．膜間領 域で層流であるとすればトレーサーは膜間領域に封 じ込められるか，少なくとも広がりが遅れると考え られる.トレーサーが注入点から拡散したというこ とは膜間領域内も乱流であることを示している. 


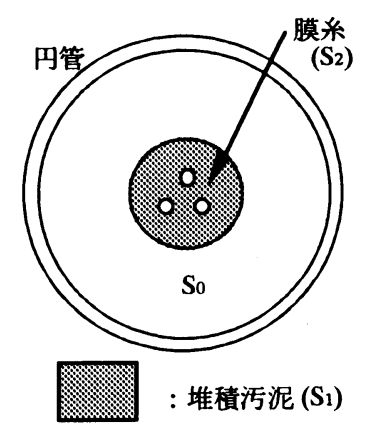

图-17 污泥堆積時の流路の収縮

また膜糸を設置した場合と, ヘッド部のみで膜系 を設定していない場合との乱れ強度の違いを調べる ために, 膜間距離 $3.2 \mathrm{~mm}$ の膜モジュールと, ヘッド 部のみで膜系を設定していない場合とでトレーサー の広がりの違いを調べた. 複数の写真からトレー サーの広がり角度を調べた.

膜糸が存在しない場合, その広がり角度は平均 2.2 $\times 10^{-1} \mathrm{rad}$, 分散 $7.0 \times 10^{-2} \mathrm{rad}$, 膜糸が存在している場 合は広がり角度は平均 $2.6 \times 10^{-1} \mathrm{rad}$, 分散 $6.0 \times 10^{-2} \mathrm{rad}$ であった. 広がりの違いは 2 割程度であり, ヘッド 部の有無によって 3 倍以上の差が出たことと比較す ると全般的な乱れ強度は膜系の存在によって大きく 異なることはないといえる.

\section{c) 膜系问の乱れ強度}

膜系間における乱れ強度について考察する.

膜間領域では時間平均流速のみを測定し, 乱れ強 度は測定していない。 また, トレーサー実験によ り，膜間距離が小さい場合であってもその膜間領域 全体が層流になっているわけではないという結果を 得たが, 乱れ強度そのものの值は得ていない.

乱れ強度が異なっている可能性としては, 膜間領 域で境界層を形成することにより，乱れが抑制され ているという状態が考えられる.

境界層には層流境界層と乱流境界層とがある。 ず，層流境界層であるとした場合，膜間領域全体で 層流境界層を形成しているわけではないことはト レーサー実験により明らかである. 膜系表面の近傍 にのみ層流境界層を形成している可能性はあるが,

膜間領域全体が層流境界層であるということはな く，必ず境界層外部の領域が膜間領域にまで及んで いる，つまり，膜間領域外部の乱れ強度之同程度の 乱れ強度が膜間領域にまで及んでいるといえる.

乱流境界層の場合、粘性底層以外では乱強度は 大きく低下することはないことが知られている．膜 間流速は膜系を設定していない場合の流速と比較し て 1 割以下の速度低下しか示しておらず, 粘性底層
が膜間領域の支配的な領域のわけではないことがわ かる.

$y=11.4 v / u_{*}\left(y\right.$ : 粘性底層厚さ, $v$ :動粘性係数. $u_{*}$ :摩 擦速度）を用いて粘性底層厚さを評価すると $0.1 \mathrm{~mm}$ 程度であった（付録参照）。この評価からも膜間領 域のほとんどの部分では，粘性底層以外の外部領域 に属していると言え, 乱れ強度は膜間領域外側の乱 れ強度と変わらないと考えられる。

\section{3. 污泥堆糟過程を支配する因子に関する考察}

\section{（1）クロスフロー流速と最大污泥付养吾}

図ー10によると最大污泥付着量はクロスフ ロー流速が大きくなるに従い小さくなってい る. $0.70 \mathrm{~m} \cdot \mathrm{s}^{-1}$ 以上ではほとんど污泥の堆積を起 こしていない.

一定以上のクロスフロー流速では污泥堆積を起こ さなくなる限界クロスフロー流速が存在している.

そこで, 付着した污泥による流路の収縮によって最 大污泥付着量に達した状態では限界クロスフローに なっているのではないかと予測できる．污泥堆積が 起きた場合, 污泥の堆積は膜モジュールを包み込む ように成長することが（図－17）観察された。一 旦そのような成辰が始まると, 最大污泥付着量に達 するまで成長し，その值は限界クロスフロー流速に よって決まるのではないかと考えられる.

そこで $0.53 \mathrm{~m} \cdot \mathrm{s}^{-1}, 0.62 \mathrm{~m} \cdot \mathrm{s}^{-1}$ の各結果において最大 污泥付着量に達したときの収縮した流路内でのクロ スフロー流速を計算した.

流路内でのクロスフロー流速を $v_{c}\left[\mathrm{~m} \cdot \mathrm{s}^{-1}\right]$, 初期状態 でのクロスフロー流速を $v_{0}\left[\mathrm{~m} \cdot \mathrm{s}^{-1}\right]$. 流路の収縮率を $e[-]$, 管の断面積を $S_{0}\left[\mathrm{~cm}^{2}\right]$, 膜糸の断面積を $S_{1}\left[\mathrm{~cm}^{2}\right]$. 污泥堆積層の断面積を $S_{2}\left[\mathrm{~cm}^{2}\right]$ とすると.

$$
v_{c}=\frac{v_{0}}{e}=\frac{S_{0}}{S_{0}-\left(S_{1}+S_{2}\right)} v_{0}
$$

となる. 污泥堆積層厚さは流れにわたって一様で あると仮定すると, 式(5)から限界クロスフロー流速 を求めることができる. クロスフロー流速 $0.53 \mathrm{~m} \cdot \mathrm{s}^{-1}$ の場合は最大污泥付着量 $0.6 \mathrm{~g} \cdot \mathrm{cm}^{-1}, 0.62 \mathrm{~m} \cdot \mathrm{s}^{-1}$ の場合 は0.3 $\mathrm{g} \cdot \mathrm{cm}^{-1}$ であった.これらの值に基づき計算を行 うと, $0.53 \mathrm{~m} \cdot \mathrm{s}^{-1}$ の場合は流路内での流速は $0.66 \mathrm{~m} \cdot \mathrm{s}^{-1}$, $0.62 \mathrm{~m} \cdot \mathrm{s}^{-1}$ の場合は $0.71 \mathrm{~m} \cdot \mathrm{s}^{-1}$ という值を得た.この值 は, クロスフロー流速 $0.7 \mathrm{~m} \cdot \mathrm{s}^{-1}$ 以上での滤過ではほと んど污泥の堆積を起こしていないという結果とも一 致する.

このことより限界クロスフロー流速 $0.7 \mathrm{~m} \cdot \mathrm{s}^{-1}$ が, 污 泥堆積が起きうるかどうかの上限を決めていること 
がわかる. また限界クロスフロー流速に達したとき の剪断応力を求めると, $2 \times 10^{2} \mathrm{~Pa}$ であった（付録参 照）. 最大污泥付着量は限界剪断応力によって規定 されていると考えられる.

\section{（2）腊系眍置と污泥堆程閐始時间}

\section{a) 膜问领域における平均流速と乱れ強度}

図ー7, 図ー8を見ると膜間距離による污泥堆積 過程の違いは主として污泥堆積開始時間の違いとし てあらわれているのが分かる. 図一7によると污泥 堆積開始時間は膜間距離 $0.8 \mathrm{~mm}$ 程度を極小として下 に凸の変化をしており, 污泥堆積開始時間の違い は, 一定時間濾過した後污泥堆積が起こるかどうか の差にあらわれる. 図ー10によると污泥堆積が起 こりうるクロスフロー流速であっても, 実際に一定 の濾過時間内に堆積が起こるかどうかは膜間距離に 依存して異なっている. クロスフロー流速 $0.53 \mathrm{~m} \cdot \mathrm{s}^{-1}$ の場合, 膜間距離 $0.5 \mathrm{~mm} \sim 1.5 \mathrm{~mm}$ の範囲では一定量の 污泥堆積を起こしているが, その範囲外では污泥の 堆積量は少なくなっており, 目視によってもほとん ど污泥堆積は観察されていない.

滤過を継続することで, いずれ污泥の堆積は起こ りうるものの, その污泥堆積開始時間が大きく異な る. 堆積開始までの時間が㥁過時間よりも長い場 合, 結果として污泥堆積が起きてないといえる.

污泥堆積開始時間が膜間距離によって大きく異な る原因は，膜間領域において流速が低下しているた めではないかと考え膜間領域の時間平均流速を測定 した. しかし, 污泥堆積が早くに起こる膜モジュー ル（膜間距離0.5 $1.5 \mathrm{~mm}$ ）も，その膜間領域での 速度は一定であり，また乱流であるという点でもそ れ以上の膜間距離をもつモジュールと変わりはな かった。

乱流であってもその乱れ強度が膜間領域で低下し ている可能性がある. しかし境界層に関する考察に よって, 乱れ強度も膜間領域の外側と比較して大き く変わってはいないであろうことが示された.

平均流速と乱れ強度の違いからは污泥堆積開始時 間に大きな違いがあることは説明できない．污泥堆 積開始時間に差を与えるものとしては別の要因が支 配しているのではないかと考えられる. そこで以下 の節では污泥堆積開始時間を記述しうるモテルに関 する考察を行った.

\section{b) 污泥粒子の兴动のシミュレーションに基づく污泥 堆程開始時间の予测}

粒子の膜面への衝突頻度に関するモデル

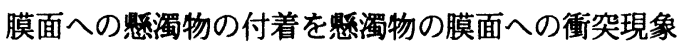
から説明することを試みた. それらに類する試みと

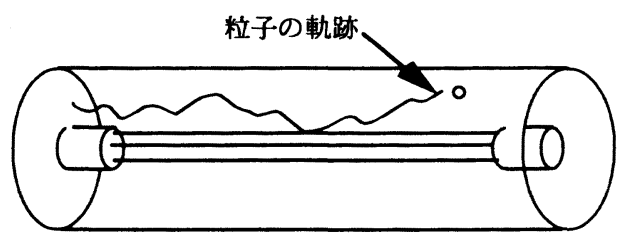

図ー18 クロスフロー中における粒子の軌跡

しては, 㦟濁物の膜面への進入角度から説明する方 法11や, 膜面への衝突回数から説明する方法 ${ }^{12}$ などが 考えられる.ここでは膜面への衝突回数から説明す る方法を用いて考察する. 污泥堆積はフロックの衝 突による付着が主要な原因であるとし, 污泥の増殖 の影響は無視した.

ここでは污泥粒子のクロスフロー中での挙動を記 述し（図一１8），その粒子の膜系への衝突分布に ついて調べた．そしてそれに基づいて膜間距離に依 存する污泥堆積開始時間の違いを考察した. 污泥粒 子の膜系への衝突分布は, 次のようなモデルから導 出した：（1）污泥粒子は独立に運動し各粒子は流 体の乱れと連動して動く（2）また污泥粒子の膜 面の衝突の際は弾性衝突をし運動量を失わない.

（3）污泥粒子の運動の記述に際しては粘性底層の 影響を無視できる.

水理条件に関しては次のように定めた：変動の Lagrange自己相関は凍結乱流の仮定に基づきEuler自 己相関から記述し、管路中心付近での現象を追うこ とになるので（図一17），乱れは一様，等方的で あると見なす．膜系近傍では膜系による壁面の粘性 底層の影響が考えられるが, 膜糸の壁面の占める割 合は, 円管の壁面と比較すると $1 / 100$ 程度であり, そ の影響は膜面のごく近傍を除いては無視で出来ると 考えている.

これらから．粒子の移動距離の分散は,

$$
\begin{aligned}
\overline{d^{\prime 2}(\Delta t)} & =\overline{\left(U \Delta t-\int_{t}^{t+u} t(\tau) d \tau\right)^{2}} \\
& =\overline{u^{2}} \int_{0}^{\Delta} \int_{0}^{x} R_{t}(x-y) d x d y
\end{aligned}
$$

と表される.

ここに,

$d^{2}$ : 粒子の移動距離の分散 $\left[\mathrm{m}^{2}\right], U$ : 平均流速 $\left[\mathrm{m} \cdot \mathrm{s}^{-1}\right], u:$ 瞬時流速 $\left[\mathrm{m} \cdot \mathrm{s}^{-1}\right], \Delta t:$ 時間ステップ [s]. $u^{\prime}:$ 乱れ強度 $\left[\mathrm{m} \cdot \mathrm{s}^{-1}\right], R_{t}(\tau):$ ラグてにおける速度 変動の自己相関保数 [-]である. $u^{\prime} お よ ひ ゙ R_{t}(\tau)$ は図一 15 に示した測定結果から導出される.

污泥粒子が乱れと連動して動くことの妥当性は污 泥の粒径と乱れのスケールとの比較で判断できる. 


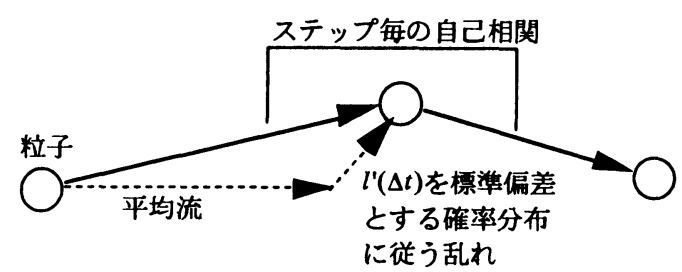

図ー 19 污泥粒子の挙動の決定

污泥の粒径は粒度分布計（堀場製作所, CAPA-4000) で測定し平均粒径約 $40 \mu \mathrm{m}$ を得た。乱れの渦の代表 スケールである Taylor scale は数百 $\mu \mathrm{m}$ であり（付録 参照），污泥粒子の大きさは乱れスケールと比較し て十分小さく, 污泥粒子が流体と連動して動くと仮 定することができる.

これらの仮定に基づき，图ー19に示したように 相関の及ぶ範囲の時間ステップを選んでステップご との粒子の動きを与えた.

本シミュレーションでは, 活性污泥中での粒子の 挙動が, 污泥の堆積現象を支配していると考えてい る. そこで, 膜系の分散度と, 粒子の拡散の度合い との比が指標として重要であると考え, 無次元化さ れた膜間距離を, 以下のように定めた.

$$
\lambda=\frac{l}{d^{\prime}\left(t_{s}\right)}
$$

ここに, $\lambda$ :無次元化された膜間距離 $[-], l:$ 膜間距離 $[\mathrm{mm}], d^{\prime}(t): t$ 秒経過した後の粒子の移動距離の標準偏 差 $[\mathrm{m}], t_{s}$ : 自己相関係数を積分して得られる時間ス ケール[s]である. $t_{s}$ は,

$$
t_{s}=\int_{0}^{\infty} R_{t}(\tau) d \tau
$$

と計算される.ここに $R_{t}(\tau)$ : 自己相関係数である. $t_{s}$ は. 平均的な渦の継続時間と考えられ, $d^{\prime}\left(t_{s}\right)$ は流れ に直角な方向の粒子の搪がりのスケールを代表する ものと考えられる.すなわちれは，膜糸間の隙間の拡 がりのスケールと粒子の拡散のスケールとの比であ る.

これら粒子の挙動に関する仮定および無次元化さ れた膜間距離を用いて污泥粒子の膜面への衝突頻度 と膜間距離との関係を調べた.

図ー20に無次元化された膜間距離と, 衝突頻度 （膜糸への衝突回数/総粒子数）との関係を示した. 衝突頻度は膜間距離によらず一定である．流速分布 が膜間距離によらず一様とした場合、このモデル中 の粒子の衝突頻度も一定であることが分かる．衝突 頻度の差によっては膜間距離によって污泥堆積開始 時間が異なることを説明できない.
笛实顷度 [-]

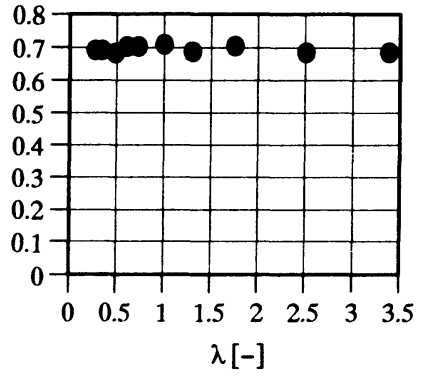

图一20 粒子か膜禾に衝突する頻度 (膜系への重突回数/総粒子数)

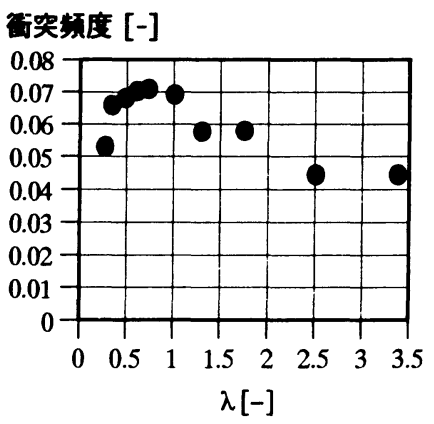

图-21粒子か膜系に 3 回以上衝突する頻度 (膜系に 3 回以上衝突する柆子の個数/総柆子数)

そこで、衝突頻度そのものが一定であっても膜間 距離が短いときは何度も膜面に衝突する粒子の数が 増加するのではないかと考え, 複数回衝突する粒子 の数をカウントした. その例として，3 回以上衝突 する粒子の, 総粒子数に対する比を図ー21に示し た. 他の回数を用いて整理しても同様の傾向が見ら れた．図を見ると，ある膜間距離の範囲ではその個 数が增加しているのが分かる.これは膜糸に囲まれ た領域に存在する粒子がより衝突しやすくなるため であると考えられる.

衝突頻度は膜間距離に依存しないが、膜間距離が 小さくなることで膜糸に囲まれた領域は膜糸によっ てより閉じられた領域となり，同じ粒子が複数回衝 突しやすくなる. 一方膜系配置の偏りによって, よ り膜糸からの距離が遠い, 衝突に関与しにくい粒子 の数が増加し，それらの粒子と衝突しやすい粒子の 数との釣り合いによって全体としての衝突頻度は一 定に保たれる. 膜間距離が非常に小さいときに複数 回衝突する粒子の数が減少するのは, 膜系に囲まれ た領域が非常に小さくなりその中の粒子そのものの 数が非常に少なくなるため, 複数回衝突する粒子数 も減少するものと考えられる. また，より衝突回数 
污泥堆積開始時間 $(\mathrm{hr})$

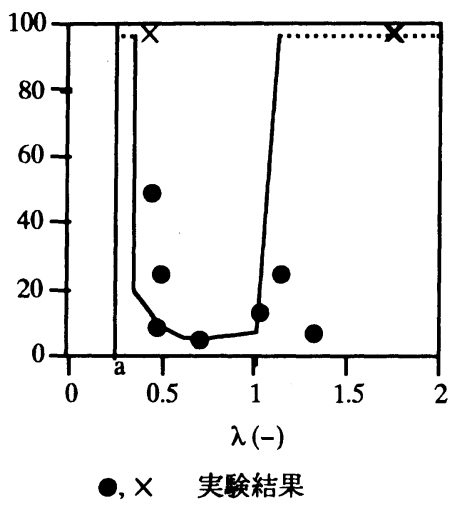

—...... シミュレーション結果

$\left(\mathrm{A}=1.0 \times 10^{-3}, \mathrm{D}=6.6 \times 10^{4},(10)\right.$ 式による $)$

滤過時間内 (96時間) に堆積を 起こさないと考えられる領域

X 滤過実酫に置いて堆積を起こさ なかった実酫結果

aの縦線は通常の意味での膜間距離 か0に相当する

図-22污泥堆積時間の実釦値と シミュレーションの比較

の多い粒子の場合，その衝突頻度の分布のピークは より入の小さい方にシフトし，その回数の釣り合い によって, 膜間距離が非常に小さい領域での衝突頻 度も一定に保たれる。

衝突頻度そのものは膜間距離によって変わること はなかったが, 複数回衝突する粒子の個数は膜間距 離が短いところで増加するという傾向を見出した. また，他の回数を用いて整理しても同様の傾向が見 られた.

そこでこれら膜面に複数回衝突する粒子が污泥堆 積開始時間の差を生じさせるのではないかと考え, 複数回膜面に衝突する粒子と污泥堆積開始時間との 関係に関するモデル化を行った.

污泥堆積開始時間のモデル化

前節の計算結果から, 総衝突頻度は膜間距離に よって変わらないものの. 複数回衝突する粒子の個 数は膜間距離によって変わり, 山なりの変化をする ことが分かった. そこでこの違いが污泥堆積開始時 間の違いに反映されていると考え, 污泥堆積開始時 間に関してさらに以下の 3 つの仮定をおいた.

（1）膜面に複数回衝突する粒子は，その一部は 膜面との接触で運動量を有意に失う結果として膜面 に付着をする。

（2）剥離頻度（初期状態における可能最大値） は水理条件（クロスフロー流速）一定のもとでは一
定とする.

（3）付着した污泥粒子が，膜表面を薄く覆うこ とで膜面の性状が変化し污泥粒子が非常に付着しや すくなることで，污泥堆積の進行が開始される.

膜面に付着を起こす粒子数は前節で計算した複数 回衝突する粒子数に一定の比率を掛けて得られる. 前節のモデルでは粒子は膜面への接触の際に運動量 を失わないと仮定し，一方ここでは付着は運動量を 失う結果起きるとしており矛盾している.

この点に関しては次のように仮定した：

潈過はクロスフローで行っており膜面に接触する 粒子数は膨大である. そして，ほとんどの粒子は膜 面に複数回接触しても失う運動量はごく僅かであ る.一方，ごくわずかの，流速分布の裾野にあたる もともと運動量の少ない粒子は，相対的により有意 に運動量を失う結果として付着を起こす.しかし， 運動量を失う割合は全体と比較すると非常に少なく 衝突分布にはほとんど影響を与えない。 それゆえ複 数回衝突分布は弾性衝突の仮定から出る衝突分布に ほぼ従う．また複数回衝突する粒子に対する，運動 量を失い付着をおこす粒子の比率は一定である.

衝突頻度と污泥堆積開始時間は以下のような関係 を持つ.

衝突頻度は $C$, 付着保数を $A$, 剥離頻度を $D$, 流路断 面を単位時間に通過する総粒子数を $N$, 粒子一個の体 積を $v$ 、膜面を覆うときの污泥付着層体積を $V$ とする と, 污泥堆積開始時間 $T$ は,

$$
V=N v(A C-D) T
$$

から求められる. 污泥堆積が開始されるきっかけ となるのは污泥粒子がちょうど膜面を単層相当覆つ た時とし，そのときの付着層厚さは污泥粒子の平均 粒径に等しい $40 \mu \mathrm{m}$ として污泥付着層堆積 $V$ を計算し た.

図ー2 2 に図ー21の結果に基づき式(10)を用い污 泥堆積開始時間を計算した結果を示した。 入が 0.7 1.2の実験データを用いパラメータフィッティン グを行い, $\lambda$ が0.5で急に污泥堆積開始時間が大きく なる領域で, 実測値とシミュレーションとの適合性 を見た. その結果, 最も実験結果と適合性のよかつ た, 3 回以上衝突する粒子数を用いて計算した結果 を同様に例として示した. 複数回の衝突分布に基づ く数値シミュレーションは実験結果をある程度再現 しうるものであることが分かる.

膜間距離が小さい領域では実験結果とのずれが大 きい. 図一2 2 は粒子が膜系に 3 回以上衝突する頻 度の分布を用いてシミュレーションをおこなってい るが, 衝突回数をかえてシミュレーションをおこ なっても膜間距離 $\lambda$ が 0.5 近傍のところでは実験結果 
とシミュレーションをこれ以上適合させることはで きなかった. 図ー 22 に示した結果はそのなかでも 比較的, 膜間領域が小さいところでの適合性がよい ものである. 膜間距離が非常に小さくなると膜糸に 囲まれた領域における境界領域などの影響が無視し 得なくなるため, 境界領域の存在を無視している本 シミュレーションでは実験值とのずれが生じている のではないかと推測される.

\section{4. 結論}

本研究で得られた結果をまとめると以下のように なる.

（1）中空糸膜による外圧式の濾過においては. クロスフロー流速がある値, 限界クロスフロー流速 以下になると污泥堆積を引き起こす. 污泥堆積が起 きる条件における污泥付着量も限界クロスフロー流 速から説明でき, その值は $0.7 \mathrm{~m} \cdot \mathrm{s}^{-1}$ であった.

（2）限界クロスフロー流速における污泥堆積層 表面の剪断応力は $2 \times 10^{2} \mathrm{~Pa}$ と見積もられた.

（3）污泥堆積が起きうるクロスフロー流速下で は污泥堆積開始時間は膜間距離に大きく影響され る. しかしいったん污泥堆積が開始されると污泥堆 積速度は膜間距離に大きく影響を受けない。

（4）膜間距離の違いによる污泥堆積開始時間に 与える影響を調べるために膜間流速を測定した. 膜 間距離によらず膜間流速は一定であった．また乱れ 強度に関する考察も行ったが, 乱れ強度も大きく異 なっているとはいえなかった. 污泥堆積開始時間の 違いは水理学的な差によらず生じることが分かっ た.

（5）そこで膜糸に曲まれた領域の污泥粒子の, 膜糸への衝突分布をシミュレートすることによって 污泥堆積開始時間を説明することを試みた. 污泥粒 子の衝突頻度. 付着係数, 剥離頻度を定式化し, 污 泥堆積は膜面を単首分污泥粒子が覆ったとき膜表面 の性状が変化し污泥堆積が開始されるとしたモテル により, 各膜間距離による污泥堆積開始時間をある 程度再現することができた.

以上の結果を応用すると, あるクロスフロー流速 下で污泥堆積しうるかどうか判定することができ, また污泥堆積が起きうるクロスフロー流速下でも. 膜間距離によってある滤過時間内に污泥堆積の進行 が開始されるかを判定することができる. 適切な設 計条件を得るには污泥堆積を起こさないためのクロ スフロー流速, 洗浄間隔, 膜糸配置を決定する必要 があり．そのための基礎的な知見を得ることができ
た.

\section{付绿}

(1)Taylor scale の導出

Taylor scale は,

$$
\lambda_{T}=\sqrt{30 \frac{v \overline{u^{\prime 2}}}{\varepsilon}}
$$

と表される ${ }^{13)}$.ここに $\lambda_{T}$ : Taylor scale[m], $v$ : 動粘性 係数 $\left[\mathrm{m}^{2} \cdot \mathrm{s}^{-1}\right], u^{\prime}$ : 乱れ強度 $\left[\mathrm{m} \cdot \mathrm{s}^{-1}\right], \varepsilon$ : 乱れエネルギー 散逸 $\left[\mathrm{m}^{2} \cdot \mathrm{s}^{-3}\right]$, である。 また，

$$
\varepsilon=g U I=f \frac{U^{3}}{2 D}
$$

と表される.ただし， $g$ : 重力加速度 $\left[\mathrm{m} \cdot \mathrm{s}^{-2}\right], U$ : 平 均流速 $\left[\mathrm{m} \cdot \mathrm{s}^{-1}\right], I:$ エネルギー勾配 $[-], f$. 摩擦損失係数 $[-], D:$ 管径 $[\mathrm{m}]$ である. 式(1), 式(2) より $\lambda_{T}$ が求めら れる. 自己相関係数は熱線流速計による測定によっ て膜モジュールのヘッド部の有無ではほとんど変わ らなかった. そこで, Taylor scaleはモジュールの存 在の有無にかかわらす一定であると考えヘッド部が 存在しない円管流の測定結果から導出し, $\lambda_{T}=1.2 \times$ $10^{-4}[\mathrm{~m}]$ という結果を得た.これより Taylor scale は数 百 $\mu \mathrm{m}$ のオーダーであることが分かる.

(2)膜表面の剪断応力の評価

膜表面の剪断応力は, 円管壁面の剪断応力に等し いとして計算する.

すると剪断応力は乱れエネルギー散逸を用いて表 すと.

$$
\tau_{b}=\frac{1}{8} f \rho U=\frac{\rho D}{4} \frac{\varepsilon_{m}}{U}
$$

となる. ただし $\tau_{b}$ : 剪断応力 $[\mathrm{Pa}], \varepsilon_{m}:$ ヘッド部が 存在する場合の乱れエネルギー散逸 $\left[\mathrm{m}^{2} \cdot \mathrm{s}^{-3}\right]$ である.

$\varepsilon_{m}$ はへッド部の存在によって異なると考えられ直接 式(2)から導出することはできない，そこでTaylor scaleはへッド部の存在によらず一定であることを用 いて $\varepsilon_{m}$ を導出する. Taylor scale一定より.

$$
\frac{\lambda_{J_{m}}}{\lambda_{T}}=\sqrt{\frac{\varepsilon}{\varepsilon_{m}}} \sqrt{\frac{\overline{u_{m}^{12}}}{u^{2}}}=1
$$

となる. $\lambda_{T_{m}}$ : 膜モジュールを設定した場合のTaylor scale [m], $\varepsilon_{m}$ および $u_{m}$ 'は膜モジュールを設定している 場合の乱れエネルギー散冕および乱れ強度である. $u_{m}^{\prime}$ および $u^{\prime}$ は実験により既知であるので式(4)より $\varepsilon_{m}$ を定めることができる.

こうして求められた $\varepsilon_{m}$ を式(3)に代入してせん断応 
力を求めると, $\tau_{b}=2 \times 10^{1}[\mathrm{~Pa}]$ となった.

(3)膜表面の粘性底層厚さの評価

粘性底層厚さは

$$
\delta=11.6 \frac{v}{u}
$$

となる．ただし $\delta$ : 粘性底層厚さ $[\mathrm{m}], v$ : 動粘性係 数 $\left[\mathrm{m}^{2} \cdot \mathrm{s}^{-1}\right], u_{*}$ : 摩擦速度 $\left[\mathrm{m} \cdot \mathrm{s}^{-1}\right]$ である.

u*は

$$
u=\sqrt{\frac{\tau_{b}}{\rho}}
$$

である．ただし $\rho:$ 暞濁液密度 $\left[\mathrm{kg} \cdot \mathrm{m}^{-3}\right]$ である．ま た，䘯は(3)式から計算できる.

これより $\delta$ を計算すると, $\delta=0.09 \sim 0.1 \mathrm{~mm}$ とな る.

\section{参考文献}

1) 長岡裕, 綾日出教, 持田悦夫, 屋井裕幸 : 中空糸膜分離 活性污泥法の処理特性一膜モジュール, 運転条件の相違 による一, 第 30 回下水道研究発表会講演集, pp.569571, 1993.

2)二村修，小島良三, 竹内清 : 膜分離一体型活性污泥法に よる連続処理試硂, 第 29 回下水道研究発表会講演集, pp.435-437, 1992.

3) 大能那夫紀, 奥野裕, 青井透, 真柄泰基 : 屎尿処理に用 いた回転平膜装置の処理特性, 第 30 回環境工学研究 フォーラム講演集, pp.19-21, 1993.

4) 松本伸吾, 松田恒男, 鳴上善久, 徳島幹治: 浸漬型セラ ミック膜分離を用いた活性污泥排水処理システムの開
発, 第 30 回環境工学研究フォーラム講演集, pp.16-18, 1993.

5) 後藤光亀, 土方隆, 平田強, 田口勝久, 佐藤敦久 : ク口 スフロー型限外万過の逆洗浄過程に関する基礎研究, 衛 生工学研究論文集, Vol. 28, pp. 131 138, 1992.

6) 荒井一仁, 長岡裕 : 直接浸漬型膜分離活性污泥法におけ るモジュール形態および吸引サイクルの評価，水環境学 会誌, Vol. 18, No. 4, pp. 324-331, 1995.

7) 柳根勇, 榷井清至, 原田秀樹 : 管状限外了過膜における 膜透過流束に影響を及ぼす因子に関する研究, 衛生工学 研究論文集, Vol. 30, pp. 303-310, 1993.

8) 西村和之, 河村清史, 真柄泰基 : 活性污泥憩濁液の膜分 離における透過フラックスに関する研究, 衛生工学研究 論文集, Vol. 29, pp. 85-91, 1992.

9) Wong, Y. K., Yamamoto, K., Ohgaki, S.: Optimal fiber spacing in externally pressurized hollow fiber module for solid liquid separation, Water Sci. and Tech., Vol. 26, pp. 1246 1254, 1992.

10) Pennell, W. T. , Sparrow,E. M. Eckert, R. G. : Turbulence intensity and time-mean velocity distributions in low Reynolds number turbulent pipe flows, $J$. Mass transfer, Vol. 15, pp. 1067 1074, 1972.

11) 長岡秀男, 入谷英司, 村瀬敏朗: 精密万過特性に及ほ すケーク構造の影䈉, 化工年会講演要旨集、No. $56, \mathrm{p}$. 419, 1991.

12) Schmitz, P., Houi, D. :Statistical model of particle accumulation on a membrane during a cross-flow microfiltration operation, I. C. O. $M$ ' 90 , pp. 767 769, 1990.

13) 中村育雄 : 乱流現象, 朝倉書店, pp. 78 105, 1992.

(1995. 8. 16 受付)

\section{A STUDY ON SLUDGE ACCUMULATION PROCESS IN THE EXTERNALLY PRESSURIZED FILTRATION OF ACTIVATED SLUDGE SUSPENSION USING HOLLOW FIBER MEMBRANES \\ Noritatsu OZAKI and Kazuo YAMAMOTO}

The dependency of accumulation process of sludge on the arrangement of membrane threads and on the crossflow velocity is investigated. The results showed that above a certain crossflow velocity, the accumulation do not occur. Further, threads arrangement was found to be influencing the sludge accumulation. But velocity and turbulence intensity in the space between membrane threads are constant independent of threads arrangement. So, a model is proposed that can explain beginning of sludge accumulation. This simulation is based on the collision of sludge particles onto the surface of membranes. 